\title{
STRATEGI KEBAHASAAN PRESIDEN JOKOWI DALAM MENANAMKAN IDEOLOGI DAN MANIFESTO PEMERINTAHAN
}

\author{
Rangga Asmara \\ FKIP Universitas Tidar \\ email: asmara@untidar.ac.id
}

\begin{abstract}
Abstrak
Penelitian ini bertujuan mendeskripsikan strategi kebahasaan Presiden Jokowi dalam menanamkan ideologi dan manifesto pemerintahan.Penelitian menggunakan analisis wacana kritis model van Dijk. Sumber data penelitian adalah teks pidato Presiden Jokowi berjudul Di Bawah Kehendak Rakyat dan Konstitusi. Pengumpulan data menggunakan analisis dokumen dengan menelusuri struktur mikro dan makro. Hasil penelitian menunjukkan bahwa terdapat empat strategi kebahasaan, yaitu strategi leksikon, stilistika, pronomina, dan sintaksis. Pada strategi leksikon dan stilistika ditemukan kosakata yang bervisi kelautan dan kerja sehingga membedakannya dengan presiden sebelumnya dan mencitrakan diri sebagai penjelmaan Soekarno. Pada strategi pronomina, Jokowi berusaha mengacaukan struktur dan mengaburkan makna pronomina: saya, kami, kita, dan rakyat sehingga membangkitkan kemenyatuan. Pada strategi sintaksis digunakan kalimat positif dan negatif untuk menokohkan diri (glorifikasi).
\end{abstract}

Kata kunci: strategi kebahasaan, ideologi, dan manifesto pemerintahan

\section{PRESIDENT JOKOWI'S LANGUAGE STRATEGIES IN INCULCATING THE IDEOLOGY AND GOVERNMENT'S MANIFESTO}

\begin{abstract}
This study aims to describe President Jokowi's language strategies in inculcating the ideology and government's manifesto. It employed van Dijk's critical discourse analysis model. The data source was Jokowi's speech text entitled Di Bawah Kehendak Rakyat dan Konstitusi. The data were collected using document analysis by tracing micro- and macrostructures. The findings show that there are four language strategies, i.e. lexical, stylistic, pronominal, and syntactic strategies. In the lexical and stylistic strategies, there are some words referring to marine and work, distinguishing Jokowi from the former presidents and creating his image as the incarnation of President Soekarno. In the pronominal strategy, Jokowi tries to turn the structure upside down and to blur the meanings of the pronouns saya, kami, kita, and rakyat in order to stimulate the unity. In the syntactic strategy, he uses both positive and negative sentences for his glorification.
\end{abstract}

Keywords: language strategies, President Jokowi, ideology, government's manifesto

\section{PENDAHULUAN}

Bahasa memiliki arti yang penting dalam dunia politik. Bahasa menjadi media yang ampuh untuk menanamkan ideologi, merebut atau mendapatkan, serta mempertahankan kekuasaan (Asror, 2015:48). Lebih lanjut Suliastianingsih
(2009:17) menyebut berbagai piranti kebahasaan dimanfaatkan untuk meraih simpati, menarik perhatian, dan membuat persepsi terhadap suatu masalah, mengendalikan pikiran, perilaku serta nilai yang dianut khalayak. 
Bahasa berfungsi sebagai sarana dalam melakukan kontrol ideologis dan kontrol kekuasaan (Haryatmoko, 2010). Proses-proses penanaman ideologis dan pengontrolan kekuasaan memerlukan bahasa sebagai alat ekspresi. Salah satu alat ekspresi yang sering digunakan untuk meneguhkan ideologi adalah melalui pidato politik atau pidato kenegaraan.

Pidato merupakan bentuk penggalangan kekuasaan melalui media massa dengan memanfaatkan fitur-fitur linguis-tik. Melalui pidato di media massa, politisi berusaha membujuk masyarakat dengan persuasinya. Pidato politisi juga merupakan sarana yang bertujuan membentuk persepsi dan meraih simpati publik. Thomas dan Wereing (2007:52-53) mengemukakan bahwa penggalangan kekuasaan dan penegakan terhadap keyakinan-keyakinan politik dapat dilalakuan dengan dua cara, yakni (1) mencari kekuasaan lewat kekerasan, dan (2) membujuk orang untuk patuh secara sukarela.

Jupriono (2010) menegaskan pidato sebagai sebuah teks adalah satu sistem tanda tergorganisasi yang merefleksikan sikap, keyakinan, dan nilai-nilai tertentu. Setiap pesan dalam pidato memiliki dua tingkatan makna, yaitu makna yang dikemukakan secara eksplisit di permukaan dan makna yang dikemukakan secara implisit di balik pidato (Kusrianti, 2004:1). Sebagaimana pidato kenegaraan perdana presiden-presiden sebelumnya, pidato perdana Presiden Jokowi pada tanggal 20 Oktober 2014 di muka sidang paripurna mengandung daya pikat dan daya pengaruh yang tinggi dan dapat menggiring masyarakat luas mengambil keputusan atau tindakan yang sesuai dengan manifesto pemerintahan yang ingin dia usung dalam menjalankan pemerintahannya lima tahun ke depan. Kemasan isi pidato politik dan pidato kenegaraan selalu dibuat untuk membuat citra tokoh yang menyampaikannya sebagai penyambung lidah rakyat.
Pidato kenegaraan perdana Presiden Jokowi menarik untuk dicermati dan dikaji secara mendalam dari sudut pandang pendekatan formal, sosiologis-empiris, dan kritis. Sebagaimana halnya Baryadi (2015:4) membagi pendekatan dalam analisis wacana ke dalam (1) pendekatan formal, (2) pendekatan fungsional, dan (3) pendekatan kritis.

Pendekatan formal memahami wacana sebagai tataran kebahasaan yang lebih tinggi dari kalimat (Baryadi, 2015:5). Pendekatan formal mengkaji wacana dari segi jenis, struktur, dan hubungan bagian-bagiannya. Pendekatan fungsional memahami wacana sebagai peristiwa tutur yang terikat konteks situasi (Baryadi, 2015:9). Pendekatan ini mengkaji wacana dalam kaitannya dengan konteks situasi secara pragmatis. Pendekatan kritis menempatkan wacana sebagai power (Baryadi, 2015:7). Wacana dipandang sebagai sebuah cerminan dari relasi kekuasaan dalam masyarakat (Renkema, 2004:282). Pendekatan kritis (CDA) memahami wacana (lisan maupun tertulis) sebagai bentuk praktik sosial (Wodak, 2006; Renkema, 2004). Seseorang memiliki tujuan berwacana, termasuk menjalankan kekuasaan.

Wacana dalam pidato termasuk pidato kenegaraan atau pidato politik sangat identik dengan muatan kekuasaan. Pembaca atau pemirsa menjadi pihak yang terdominasi oleh pihak yang sedang berorasi. Mereka dengan mudah dikontrol secara ideologis dan bahkan diarahkan untuk melakukan tindakan tertentu. Praktik demikian merupakan bentuk praktik pendominasian melalui bahasa. Pierre Bourdieu (Haryatmoko, 2003:5) menyebut praktik ini sebagai determinan kultural-ideologis. Sebuah bentuk praktik dominasi dari kelas yang berkuasa melalui kooptasi institusional dan manipulasi sistemis atas teks dan penafsirannya.

Pendominasian pada dasarnya mencakup bagaimana seseorang, kelompok, 
tindakan, kegiatan ditampilkan dalam teks. Pendominasian dapat dilihat dari dua hal, yakni (1) peran dan posisi aktor dan (2) gagasan yang ditampilkan dengan menggunakan kata, kalimat, dan wacana yang dirangkai untuk membangun tujuan tertentu. Eriyanto (2012:53) mengklasifikasi tiga aspek pendominasian, yakni (1) isi, yaitu hal-hal yang diucapkan atau dilakukan, (2) relasi, yaitu hubungan sosial yang dimasukkan dalam wacana, dan (3) subjek atau posisi yang ditempati seseorang.

Sebagai salah satu bentuk praktik sosial, pidato perdana Jokowi bukan hanya dipandang dari persoalan linguistik, tetapi ekspresi ideologi untuk membentuk pendapat umum mengenai identitas atau citra dirinya. Jokowi bukan politikus yang pandai bicara. Gaya pidato Jokowi, meskipun tertulis dan dibacakan, tetaplah terasa lisan. Spontanitasnya mencerminkan kepribadian seorang yang tumbuh dari bawah. Gaya Jokowi ini memang berbeda dengan para presiden Indonesia sebelumnya, meski wujud formal teks pidatonya banyak menyitir konsepsi dan retorika presiden pertama Indonesia Soekarno.

Untuk dapat merebut simpati dan menanamkan ideologi, Jokowi memainkan strategi dan metode berpidato yang berbeda dengan gaya presiden-presiden sebelumnya untuk memasarkan manifesto pemerintahannya. Bahasa tidak dapat dipandang sebagai entitas yang netral, tetapi memiliki ideologi yang membawa muatan kekuasaan tertentu (Jufri, 2005:1). Ideologi dan kekuasaan tercermin dalam pemakaian kosakata, kalimat, dan struktur wacana. Dalam konteks pidato politik atau pidato kenegaraan, fitur-fitur bahasa tersebut dijadikan sebagai sarana untuk menanamkan ideologi dan menifesto, merebut simpati, serta meneguhkan kekuasaan.

Berdasarkan paparan tersebut, kajian ini dibatasi pada (1) eksplorasi strategi menanamkan ideologi dan manifesto pemerintahan yang dieksplisitkan pada profil kebahasaan pidato Jokowi dan (2) interpretasi kritis atas fakta-fakta yang diimplisitkan dalam pidato Jokowi.

\section{METODE}

Dalam penelitian ini digunakan metode penelitian linguistik dengan model analisis wacana kritis Teun A. van Dijk. Van Dijk membangun suatu model yang mengintegrasi secara bersama-sama analisis wacana yang didasarkan pada fiturfitur linguistik melalui pemikiran sosial, politik, dan secara umum diintegrasikan pada perubahan sosial. Oleh karena itu, analisis harus dipusatkan pada bagaimana bahasa itu terbentuk dan dibentuk dari relasi sosial dan konteks sosial tertentu (Eriyanto, 2012:286).

Metode analisis dokumen sengaja dipilih dalam kajian ini. Data yang dianalisis bersumber dari wacana teks pidato perdana Presiden Jokowi yang berjudul "Di Bawah Kehendak Rakyat dan Konstitusi". Data ini dibangun dari 17 paragraf. Instrumen riset yang dipakai adalah $h u$ man instrument, yakni kecermatan dan kepekaan penulis dalam menangkap dan membedah data.

Teknik analisis data dalam penelitian ini menggunakan model analisis van Dijk. Analisis disisir dari elemen struktur mikro dan struktur makro. Secara formal struktur mikro dikonsentrasikan pada analisis leksikal dan gramatikal, sedangkan analisis struktur makro berfokus pada proses produksi dan pemaknaan dari sudut pandang ideologi dan kekuasaan.

Data dianalisis dengan mengikuti langkah-langkah sebagai berikut. Pertama, mengklasifikasi data kebahasaan yang memuat praktik diskursif sehingga dapat dirumuskan strategi kebahasaannya. Kedua, menginterpretasi kritis atas maksud/motif terselubung di balik strategi kebahasaan yang digunakan Jokowi berdasarkan konteks situasi dan latar wacana yang relevan. 


\section{HASIL DAN PEMBAHASAN}

Strategi Kebahasaan Presiden Jokowi dalam Menanamkan Ideologi dan Manifesto Pemerintahan

Strategi kebahasaan Jokowi dalam menanamkan ideologi dan menifesto pemerintahan dilakukan dengan memanfaatkan aspek-aspek formal teks pidatonya yang berjudul Di Bawah Kehendak Rakyat dan Konstitusi. Dalam teks pidatonya, Jokowi menonjolkan struktur mikrowacana pada level leksikal dan gramatikal. Pada kedua level tersebut diinterpretasi secara kritis fakta-fakta yang diimplisitkan dari proses produksi dan ideologinya. Pada level leksikal digunakan strategi (1) leksikon, (2) stilistika, dan (3) pronomina sedangkan pada level gramatikal digunakan strategi sintaksis.

\section{Strategi Leksikon}

Dalam upaya merebut dukungan dan simpati publik, Presiden Jokowi menggunakan strategi leksikon. Strategi ini mengekspos kosakata yang memiliki referen kemaritiman. Pemilihan ini didasarkan pada ekspos fakta sejarah masa lalu sebagai komponen latar (setting) pidato. Selain itu, dia berusaha teguh pada patron kepemimpinannya yang identik dengan blusukan, namun dikemas dengan diksi yang lebih positif yaitu kerja, kerja, dan kerja. Klasifikasi tersebut bertujuan memberikan ciri atas diri yang dapat membedakannya dengan presiden sebelumnya, Susilo Bambang Yudhoyono (SBY) dan mencitrakan diri sebagai penjelmaan dari Bung Karno berdasarkan proses pemunculannya dan ideologi yang ada di baliknya.

Ideologi tersebut tampak dari awal mula pidato Jokowi yang menghentak publik dengan beberapa konsepsi dan retorika Bung Karno. Di bagian pembukaan, Jokowi langsung mengutip tiga butir konsep Bung Karno tentang trisakti. Sangat terasa bahwa Jokowi berusaha menghidupkan kembali konsepsi Bung
Karno tentang kemandirian politik, ekonomi, berkepribadian di bidang kebudayaan. Lebih jauh, ditemukan beberapa kosakata yang bervisi kelautan dan kerja untuk mendukung manifesto pemerintahannya lima tahun ke depan. Leksikon bervisi kelautan dan kerja yang didayagunakan oleh Jokowi yakni jalesveva jayamahe, cakrawarti samudera, kerja, kerja, dan kerja, serta nelayan sebagaimana tampak pada kutipan berikut.

Kini saatnya kita mengembalikan semuanya sehingga Jalesveva Jayamahe, di laut justru kita jaya, sebagai semboyan nenek moyang kita di masa lalu, bisa kembali membahana.

Jalesveva jayamahe adalah motto TNI Angkatan Laut yang berasal dari bahasa Sansekerta dan dapat dimaknai "di laut kita jaya". Secara ideologis, Jokowi berusaha menunjukkan inisiatif dan keinginan yang kuat untuk meraih kembali kejayaan maritim dan menjadikannya seperti semboyan nenek moyang. Selama ini dapat dikatakan bahwa bangsa Indonesia adalah "masyarakat bahari yang lupa daratan", karena sudah jauh dari jati dirinya sendiri sebagai bangsa yang besar dengan potensi lautnya. Justru letak geografis kepulauan itu bukan menjadi pendukung tetapi menjadi beban dalam pengelolaan negara.

Dalam pidatonya, Joko Widodo sebagai presiden mengajak segenap elemen bangsa untuk memiliki kesadaran maritim. Dalam kesempatan tersebut juga mengatakan secara lantang "Jalesveva Jayamahe", menegaskan kembali bahwa pengelolaan maritim adalah fokus utamanya dalam menjalankan pemerintahan lima tahun ke depan.

Mengakhiri pidato ini, saya mengajak saudara-saudara sebangsa dan setanah air untuk mengingat satu hal yang pernah disampaikan oleh Presiden Pertama Republik Indonesia, Bung Karno, bahwa untuk membangun Indonesia menjadi negara besar, negara kuat, negara mak- 
mur, negara damai, kita harus memiliki jiwa cakrawarti samudera; jiwa pelaut yang berani mengarungi gelombang dan hempasan ombak yang menggulung.

Jokowi dalam pidatonya menyitir kembali pernyataan Presiden Soekarno pada saat meresmikan Institut Angkatan Laut tahun 1953 bahwa bangsa Indonesia harus berupaya bukan sekadar menjadi jongos-jongos di kapal melainkan bangsa pelaut dalam arti kata cakrawati samudera. Cakrawati samudera adalah sebuah bangsa yang mempunyai armada niaga, armada militer, dan bangsa yang kesibukannya di laut menandingi irama gelombang lautan. Saat itu, Bung Karno mengajak seluruh rakyat Indonesia untuk mengisi kemerdekaan dengan kembali menjadi bangsa pelaut dalam arti yang seluas-luasnya.

Korelasi dari apa yang disampaikan oleh Bung Karno dengan pidato Jokowi terlihat jelas sebagai bentuk dorongan untuk menyadari pentingnya budaya bahari Indonesia. Negara yang kaya akan hasil laut, tetapi banyak kekayaan lautnya dinikmati oleh bangsa lain baik secara legal maupun ilegal sehingga tidak memberi kontribusi nyata bagi kemakmuran Indonesia. Benar kiranya, dalam 10 bulan memerintah, Jokowi betul-betul tunduk pada amanat pidato perdananya tersebut. Sudah puluhan kapal asing ditenggelamkan karena pencurian ikan. Bahkan, kapal lokal yang mencari ikan dengan bahan berbahaya pun turut ditenggelamkan. Kebijakan ini menjadi bukti keseriusan manifesto kelautan Presiden Jokowi.

Lima tahun ke depan menjadi momentum pertaruhan kita sebagai bangsa merdeka. Oleh sebab itu, kerja, kerja, dan kerja adalah yang utama.

Inilah, momen sejarah bagi kita semua untuk bergerak bersama untuk bekerja, bekerja, dan bekerja.
Jokowi melakukan repetisi leksikon kerja sebanyak 16 kali di dalam pidatonya. Pengulangan kata kerja menunjukkan bahwa kata-kata tersebut mendapatkan penekanan dan diinterpretasi sebagai langgam pemerintahannya lima tahun ke depan. Dari sudut pandang kritis, persuasi untuk kerja, kerja, dan kerja ditujukan kepada pemerintah baik pusat maupun daerah untuk tidak hanya sekadar duduk di belakang meja menunggu laporan bawahan, namun betul-betul turun dalam istilah Jokowi blusukan, untuk memerikan masalah dan merumuskan solusi berdasarkan masalah empiris di lapangan.

Melalui persuasi untuk kerja, kerja, dan kerja, tampak jelas Jokowi berupaya menunjukkan watak dan kredibitas yang dimiliki. Sebagaimana Keraf (2004:121) menjelaskan bahwa persuasi akan berlangsung sesuai harapan, jika penerima informasi telah mengenal pemberi informasi sebagai orang yang berwatak baik. Oleh karena itu, Jokowi berupaya membangun realitas subjektif atas dirinya sebagai penggagas blusukan.

Bentuk leksikal bekerja, bekerja, dan bekerja menduplikasi gaya Bung Karno yang suka mengulang beberapa kata atau frase sebagai penekanan. Strategi ini merupakan bagian untuk memeriksa apa yang ditekankan atau ditonjolkan (yang berarti dianggap penting) oleh seseorang yang dapat diamati dari teks (Sobur, 2006: 83-84). Gaya retorika lisan inilah yang membuat pidato Jokowi dianggap sebagai representasi Bung Karno, bahkan sebagian masyarakat menjuluki Jokowi sebagai "Soekarno kecil". Strategi menanamkan ideologi semacam ini mengaburkan kelemahan Jokowi dalam berorasi karena seolah-olah Jokowi telah diasosiasi sebagai Soekarno.

Kepada para nelayan, buruh, petani, pedagang bakso, pedagang asongan, sopir, akademisi, guru, TNI, POLRI, pengusaha dan kalangan profesional, saya menyeru-

Strategi Kebahasaan Presiden Jokowi dalam Menanamkan Ideologi dan Manifesto Pemerintahan 
kan untuk bekerja keras, bahu membahu, bergotong royong. Inilah, momen sejarah bagi kita semua untuk bergerak bersama untuk bekerja, bekerja, dan bekerja.

Ideologi dalam pidato yang disampaikan oleh Jokowi menunjukkan posisi strategis nelayan sebagai salah aktor utama dalam mewujudkan Indonesia sebagai negara yang kuat. Penyebutan pertama kali untuk nelayan di antara beberapa profesi yang ada, mencerminkan manifesto pemerintahan presiden Indonesia yang ketujuh ini bahwa penting untuk memacu dan memberikan perhatian khusus kepada nelayan.

Penguatan posisi strategis ini berbeda jauh dengan yang selama ini telah ada. Nelayan terutama nelayan tradisional terkesan hanya seperti pemeran figuran bahkan penonton dalam pembangunan bangsa dan negara. Terbukti dari kenyataan yang ada saat ini. Nelayan sebagian besar berada di bawah garis kemiskinan. Selain nelayan penangkap ikan, juga pembudidaya seperti petambak ikan yang belum mendapat prioritas peran dalam pembangunan nasional.

Akses permodalan yang sulit serta peningkatan SDM yang lemah turut dirasakan oleh nelayan. Pengembangan infrastruktur pendidikan yang minim di kawasan pesisir dan pulau-pulau kecil menjadi salah satu pemicunya. Di sisi lain jaminan kesejahteraan dan perlindungan bagi nelayan kecil masih jauh dari harapan. Data Badan Pusat Statistik (BPS) tahun 2014 menunjukkan jumlah nelayan di Indonesia mencapai 37 juta jiwa, $70 \%$ dari total tersebut di bawah ambang kemiskinan serta hidup dari hutang ke hutang. Salah satu penyebabnya adalah kelangkaan BBM. Nelayan sulit untuk membeli BBM jenis solar sesuai dengan harga eceran yang ditetapkan pemerintah. Ke depan, persoalan rencana kenaikan harga BBM tentu juga perlu mempertimbangkan hal tersebut.
Keberadaan nelayan akan sangat menentukan kemampuan produksi perikanan negara Indonesia, sementara karena tekanan ekonomi seperti penjelasan di atas mendorong banyaknya nelayan berpindah profesi yang termasuk mendorong terjadinya urbanisasi masyarakat pesisir ke kota besar. Hal lain yang berdampak negatif terhadap nelayan adalah perusakan lingkungan serta praktik privatisasi lahan di wilayah pesisir. Perusakan lingkungan akan menyebabkan terganggunya ekosistem sehingga hasil produksi perikanan menurun. Privatisasi atau pengkaplingan lahan di pesisir menyangkut kebutuhan tempat tinggal serta lahan alternatif bagi keluarga nelayan untuk bercocok tanam atau membudidaya ikan saat harus bertahan pada masa panceklik atau kondisi dimana tangkapan dari laut berkurang atau bahkan tidak ada. Jokowi dalam pidatonya memberikan harapan besar untuk menempatkan posisi nelayan sebagai inti pembangunanan Indonesia dan menjadi "poros maritim dunia".

\section{Strategi Stilistika}

Pusat perhatian stilistika adalah style, yaitu cara yang digunakan seseorang pembicara atau penulis untuk menyatakan maksudmya dengan menggunakan bahasa sebagai sarana. Dengan demikian, style dapat diterjemahkan sebagai gaya bahasa (Ratna, 2009:167). Selanjutnya, gaya bahasa merupakan cara memanipulasi unsur-unsur dan kaidah-kaidah bahasa untuk memberikan efek tertentu. Dalam konteks ini, Jokowi menggunakan gaya bahasa sebagai sarana estetika. Gaya bahasa yang didayagunakan Jokowi dalam pidatonya berbentuk metafora dan analogi. Dalam gaya bahasanya, kembali ditemukan leksikon bervisi kelautan dan kerja. Strategi ini tampaknya digunakan untuk mempertegas manifesto pemerintahannya lima tahun ke depan. Gaya bahasa metafora dan analogi yang bervisi kelautan dan kerja ini tampak pada pilih- 
an kata memunggungi laut dan nahkoda dan kapal.

Kita harus bekerja dengan sekeras-kerasnya untuk mengembalikan Indonesia sebagai negara maritim. Samudra, laut, selat dan teluk adalah masa depan peradaban kita. Kita telah terlalu lama memunggungi laut, memunggungi samudra, memunggungi selat dan teluk.

Jokowi mendayagunakan metafora memunggungi laut, memunggungi samudra, memunggungi selat, dan memunggungi teluk dalam pidatonya untuk mengingatkan betapa pembangunan Indonesia selama beberapa dekade terakhir terlalu bertumpu pada daratan. Padahal secara geografis, wilayah lautan Indonesia jauh lebih luas (73 persen) daripada luas daratan yang hanya 27 persen. Namun, Jokowi mungkin lupa bahwa keempat bagian berair dari konsep tanah air itu juga ada sungai. Orang dari negeri seribu sungai bisa mengembangkan ungkapan itu bahwa kita selama ini juga terlalu lama memunggungi sungai.

Sebagai nakhoda yang dipercaya oleh rakyat, saya mengajak semua warga bangsa untuk naik ke atas kapal Republik Indonesia dan berlayar bersama menuju Indonesia Raya. Kita akan kembangkan layar yang kuat. Kita akan hadapi semua badai dan gelombang samudera dengan kekuatan kita sendiri.

Jokowi juga menganalogikan dirinya sebagai nahkoda yang dipercaya oleh rakyat Indonesia. Ada kapal tanpa nakoda maka kapal tidak akan menentu arahnya dan dapat terombang-ambing oleh gelombang laut. Negara Indonesia ibarat sebuah kapal yang berlayar menuju tanah harapan. Seorang nahkoda adalah pemegang kekuasaan dan pengendali pada suatu kapal. Ajakan yang disampaikan melalui analogi tersebut kembali kepada maksud untuk bergotong royong dan mengambil peran masing-masing agar tercapailah tujuan bersama yaitu menjadikan Indonesia sebagai negara yang besar, negara yang kuat, dan negara yang damai.

\section{Strategi Pronomina}

Jokowi mempraktikan strategi permainan pronomina. Permainan pronomina dilakukan untuk mengacaukan subjek dan objek sebuah kalimat sehingga pendengar rancu. Permainan ini dapat digunakan untuk menokohkan seseorang (glorifikasi) atau menuai simpati. Dalam wacana pencitraannya, Jokowi berusaha mengaburkan makna kata saya, kami, kita, dan rakyat dengan cara menggunakannya secara bergantian seolah-olah bersinonim. Empat kata yang maknanya jauh berbeda itu dipertukarkan sehingga seolah-olah sama. Dengan cara itu, Jokowi berupaya mengajak pembaca agar dapat merasakan perasaannya. Jika berhasil, pengaburan ini akan membuat persoalan yang merupakan persoalan individu ini, seolah-oleh menjadi persoalan publik.

Dalam kajian pragmatik, kata kita merupakan bentuk inklusif atau gabungan antara persona pertama ( $a k u$, daku, saya) dan kedua (kamu, kau, dikau). Secara sederhana, kita berarti saya dan anda atau kami dan anda. Jufri (2005:35) mengemukakan bahwa kata ganti (pronomina) merupakan aspek yang dapat dimanipulasi dengan pilihan bahasa untuk menciptakan makna imajinatif. Kata ganti saya dan kami digunakan untuk mengambarkan sikap resmi komunikator semata-mata. Kata ganti kita merupakan representasi dan wujud sikap bersama dalam satu komunitas. Potensi kata kita telah disadari Jokowi dapat membangkitkan sensasi kemenyatuan. Pada pilpres lalu Jokowi memanfaatkan potensi kata kita dengan sangat baik pada tagline iklannya, "Jokowi adalah kita". Oleh karena itulah, kata ini banyak digunakan sebagai sarana pencitraan. 


\section{Strategi Sintaksis}

Fairclough (2003:138) mengemukakan bahwa ketika seseorang ingin menuangkan sesuatu yang ada dalam realitas atau sesuatu yang hanya ada dalam imajinasi, seseorang itu kerap memilih pilihan yang berbeda pada proses gramatikanya. Representasi ideologis Jokowi yang mencitrakan manifesto pemerintahannya lima tahun ke depan dituangkan dalam dua bentuk yakni kalimat positif dan kalimat negatif.

Sebagaimana Sultan (2009) menyebut baik kalimat positif maupun kalimat negatif dapat digunakan untuk mengekpresikan ideologi tertentu untuk menuai simpati dan pada ujungnya menokohkan seseorang (glorifikasi). Berikut contoh kalimat positif dan negatif dalam pidato perdana Jokowi yang memiliki muatan ideologis.

(1) Pemerintahan yang saya pimpin akan bekerja untuk memastikan setiap rakyat di seluruh pelosok tanah air, merasakan kehadiran pelayanan pemerintahan. Saya juga mengajak seluruh lembaga negara untuk bekerja dengan semangat yang sama dalam menjalankan tugas dan fungsinya masing-masing.

(2) Pada kesempatan yang bersejarah ini, perkenankan saya, atas nama pribadi, atas nama Wakil Presiden Muhammad Jusuf Kalla dan atas nama bangsa Indonesia menyampaikan terima kasih dan penghargaan kepada Bapak Prof. Dr. Susilo Bambang Yudhoyono dan Bapak Prof. Dr. Boediono yang telah memimpin penyelenggaraan pemerintahan selama lima tahun terakhir.

(3) Kita tidak akan pernah besar jika terjebak dalam keterbelahan dan keterpecahan. Dan, kita tidak pernah betul-betul merdeka tanpa kerja keras.

(4) Kerja besar membangun bangsa tidak mungkin dilakukan sendiri oleh Presi- den, Wakil Presiden ataupun jajaran Pemerintahan yang saya pimpin, tetapi membutuhkan topangan kekuatan kolektif yang merupakan kesatuan seluruh bangsa.

Muatan ideologis yang diekspresikan melalui kalimat positif nomor (1) bermakna gamblang, tegas, dan lugas. Subjek pemerintahan yang saya pimpin memiliki referen yang kuat dengan isi pidato bahwa Jokowi tidak bisa membangun Indonesia sendirian.

Kerja besar membangun bangsa tidak mungkin dilakukan sendiri oleh Presiden, Wakil Presiden ataupun jajaran Pemerintahan yang saya pimpin, tetapi membutuhkan topangan kekuatan kolektif yang merupakan kesatuan seluruh bangsa.

Penggunaan klausa persuasif merasakan kehadiran pelayanan pemerintahan akan membentuk keyakinan subjektif khalayak. Klausa tersebut menarik minat khalayak untuk meyakini keyakinan politik Jokowi. Sebagaimana Haryatmoko (2010) mengungkapkan pemakaian istilah, kata, kalimat tertentu pada akhirnya dapat mengarahkan khalayak pada pikiran dan perasaan tertentu, bahkan dapat mempengaruhi perilakunya. Klausa persuasif dipilih Jokowi untuk menekankan sikap politik dan pendapat, mengumpulkan dukungan, memanipulasi opini publik, mengkonstruksi kesadaran politik publik atau legitimasi kekuatan politik.

Begitu pun pilihan retorika dalam kalimat nomor (2) digunakan Jokowi untuk untuk menghindari konfrontasi dengan presiden sebelumnya yaitu SBY. Jokowi tidak mengambil posisi konfrontatif demi pencitraan kesantunan dan rasa hormat kepada pendahulunya. Hal itu terlihat dari ekspresi ketidaktegasan tuturannya dalam menyebut prestasi era pemerintahan SBY. Strategi ini digunakan Jokowi untuk tetap menjaga citra di mata khalayak dan juga upaya menghindari persoalan 
dualistik Megawati dan SBY. Jupriono (2010) menganggap bahwa ekspos fakta sejarah masa lalu adalah komponen latar (setting) pidato. Karena pidato kenegaraan merupakan bentuk wacana, ekspos fakta sejarah ini dianggap sebagai latar wacana (discourse setting).

Sebagaimana presiden-presiden sebelumnya, dalam isi pidato kenegaraannya, Jokowi tidak lupa berterima kasih dan memberi penghargaan kepada SBY dan Boediono yang telah memimpin pemerintahan selama lima tahun terakhir tanpa menyebut prestasi pemerintahan era SBY. Secara eksplisit, strategi ini digunakan untuk menghargai dan berterima kasih kepada jasa pemerintahan sebelumnya dan secara implisit untuk memperkuat konsolidasi guna membangun status quo.

Jokowi juga mengekspresikan pencitraan diri secara implisit melalui kalimat negatif nomor (3) dan (4) dengan menggunakan negasi tidak. Bahkan kalimat nomor (3) menggunakan negasi ganda untuk mengekspresikan secara tidak langsung pencitraannya. Penggunaan negasi ganda tersebut dilakukan untuk memberi penegasan bahwa dia betul-betul tidak bisa bekerja sendiri tanpa kerja keras dan gotong royong rakyatnya.

\section{SIMPULAN}

Strategi kebahasaan Presiden Jokowi dalam menanamkan ideologi dan menifesto pemerintahan dilakukan dengan memanfaatkan aspek-aspek formal teks pidatonya yang berjudul Di Bawah Kehendak Rakyat dan Konstitusi. Dalam teks pidatonya, Jokowi menonjolkan struktur mikrowacana pada level leksikal dan gramatikal. Pada kedua level tersebut diinterpretasi secara kritis fakta-fakta yang diimplisitkan dari proses produksi dan ideologinya. Pada level leksikal digunakan strategi (1) leksikon, (2) stilistika, dan (3) pronomina sedangkan pada level gramatikal digunakan strategi sintaksis.
Dalam upaya menanamkan ideologi dan manifesto pemerintahan, Presiden Jokowi menggunakan strategi kosakata dan stilistika yang memiliki yang referen kemaritiman dan kerja. Selain itu, dia berusaha teguh pada patron kepemimpinannya yang identik dengan blusukan, namun dikemas dengan diksi yang lebih positif yaitu kerja, kerja, dan kerja. Strategi tersebut bertujuan untuk memberikan ciri atas diri yang dapat membedakannya dengan presiden sebelumnya dan mencitrakan diri sebagai penjelmaan dari Soekarno.

Strategi pronomina dilakukan dengan mengacaukan subjek dan objek sebuah kalimat sehingga pendengar rancu. Jokowi berusaha mengaburkan makna pronomina saya, kami, kita, dan rakyat dengan cara menggunakannya secara bergantian seolah-olah bersinonim. Dengan cara itu, Jokowi berupaya mengajak pembaca agar dapat merasakan perasaannya. Jika berhasil, pengaburan ini akan membuat persoalan yang merupakan persoalan individu ini, seolah-oleh menjadi persoalan publik. Potensi penggunaan strategi pronomina telah disadari Jokowi dapat membangkitkan sensasi kemenyatuan.

Strategi sintaksis tampak dari penggunaan kalimat positif dan negatif. Dalam klausa persuasifnya, Jokowi berusaha membentuk keyakinan subjektif khalayak, mengumpulkan dukungan, memanipulasi opini publik, mengkonstruksi kesadaran politik publik atau legitimasi kekuatan politik dan untuk menghindari konfrontasi dengan presiden sebelumnya yaitu SBY. Jokowi tidak mengambil posisi konfrontatif demi pencitraan kesantunan dan rasa hormat kepada pendahulunya. Di balik strategi ini ujungnya adalah menokohkan diri (glorifikasi).

\section{UCAPAN TERIMA KASIH}

Artikel ini disusun dari penelitian mandiri yang dilaksanakan pada awal tahun 2015. Ucapan terima kasih disampaikan kepada kolega dosen Prodi

Strategi Kebahasaan Presiden Jokowi dalam Menanamkan Ideologi dan Manifesto Pemerintahan 
Pendidikan Bahasa Indonesia Universitas Tidar yang telah membantu kegiatan verifikasi, dan triangulasi data hasil penelitian. Ucapan terima kasih juga disampaikan kepada Dr. Haryatmoko yang telah memberi masukan yang berharga dan rujukan teoritis kaitannya dengan model-model analisis wacana kritis.

\section{DAFTAR PUSTAKA}

Asror, Abdul Ghoni. 2015. “Bahasa Pencitraan dalam Iklan Kampanye Pilkada Kabupaten Bojonegoro", Jurnal Magistra. Volume 26, No. 92.

Baryadi, Praptomo. 2015. "Analisis Wacana". Artikel Seminar Metode Penelitian Bahasa dalam Konteks Kekinian. Magelang: Universitas Tidar.

Eriyanto. 2012. Analisis Wacana: Pengantar Analisis Teks Media. Yogyakarta: LKIS.

Fairclough, Norman. 2003. Language and Power. Terjemahan Indah Rohmani. Malang: Boyan Publishing.

Firdaus, Randy Ferdi. 2014. "Ini Isi Lengkap Pidato Perdana Presiden Jokowi". http://www.merdeka.com/peristiwa/ ini-isi-lengkap-pidato-perdana-presiden-jokowi.html. Diakses 19 Januari 2015.

Haryatmoko. 2003. “Landasan Teoretis Gerakan Sosial Menurut Pierre Bourdieu: Menyingkap Kepalsuan Budaya Penguasa". Basis 52 (11-12), Nov.-Des.: 4-23.

Haryatmoko. 2010. Dominasi Penuh Muslihat: Akar Kekerasan dan Diskriminasi. Jakarta: PT Gramedia Pustaka Utama.

Jufri. 2005. "Penggunaan Kosa Kata dalam Wacana Berita tentan "SBY" Sekitar Pemilu 2004", Jurnal Wacana Kritis. Volume 10, Januari 2005, hal. 1-11.
Jupriono. 2010. “Analisis Wacana Kritis Latar Historis dalam Pidato Kenegaraan Presiden Susilo Bambang Yudhoyono". Jurnal Parafrase. Volume 10 No. 02.

Keraf, Gorys. 2004. Argumentasi dan Narasi. Jakarta: Gramedia.

Kusrianti, Anik. 2004. Analisis Wacana. Bogor: Pakar Raya.

Ratna, Nyoman Kutha. 2009. Stilistika: Kajian Puitika Bahasa, Sastra, dan Budaya. Yogyakarta: Pustaka Pelajar.

Renkema, Jan. 2004. Introduction to Discourse Studies. Amsterdam/Philadelphia: John Benjamin Publishing Company.

Sobur, Alex. 2006. Analisis Teks Media, Suatu Pengantar untuk Analisis Wacana, Analisis Semiotik, dan Analisis Framing. Bandung: Remaja Rosdakarya.

Suliastianingsih, Tri. 2009. "Bahasa Indonesia dalam Wacana Propaganda Politik Kampanye Pemilu 2009: Satu Kajian Sosiopragmatik". Jurnal Sosioteknologi, Edisi 17, Tahun 8, Agustus 2009.

Sultan. 2009. "Bahasa Pencitraan dalam Wacana Iklan Kampanye Calon Anggota Legislatif 2009". Jurnal Wacana Kritis, Volume 14, Nomor 2, Juli 2009.

Thomas, Linda dan Shan Wareing. 2007. Language, Power, and Society (Terjemahan Abdul Syukur Ibrahim). Yogyakarta: Pustaka Pelajar.

Wodak, Ruth. 2006. "What CDA is about: A Summary of Its History, Important Concept, and Its Development". Dalam R. Wodak \& M. Meyer (eds.). 2006. Methods of Critical Discourse Analysis. London: Sage, hlm. 1-13. 